\title{
Effects of Information and Communication Technology Adoption on the Operations of Modern Retail Outlets in Metropolitan Kano, Nigeria
}

\author{
Suraju Adewale Ramoni ${ }^{1} \quad$ Bamidele Adeboye Adepoju ${ }^{2}$ \\ 1.Department of Economics and Management Science, Nigeria Police Academy, P.M.B. 3474, Wudil, Kano \\ State, Nigeria \\ 2.Professor of Business Administration, Department of Business Administration and Entrepreneurship, Bayero \\ University Kano, P.M.B. 3011, Kano - Nigeria
}

\begin{abstract}
The retail environment is highly competitive and so, organised retail outlets in Nigeria have had to adopt InformationTechnology (IT) to enhance their operational efficiency. Thus, this study investigated key determinants of IT adoption in modern retail outlets in Nigeria, and how IT usage has enhanced operational efficiency of these outlets. Cross sectional research design was employed for the study and primary data were collected via self-administered questionnaire on the research variables from 400 respondents selected through a systematic sampling technique.The returned 351 copies of questionnaire which represented $88 \%$ response rate were analysed using frequency, percentage, Pearson correlation coefficient and regression model. It was found that the trio of organisational leadership, adopter's attitude and ease of use are significant predictors of IT adoption among staff of modern retail outlets in Nigeria and that IT adoption significantly explained $57 \%$ variations found in operational efficiency of these retail outlets. It was therefore, recommended that operators of organised retail outlets familiarise themselves with various technological innovations in the retail industry with a view to using them in order to add values to their businesses and customers.
\end{abstract}

Keywords: Information technology, adoption, organised retail outlets, retail operations and ease of use. DOI: $10.7176 / \mathrm{EJBM} / 11-2-11$

\section{Introduction}

The business world is continuously changing due to advances and developments in Information and Communication Technology (ICT). Information technology is a term that encompasses all forms of technology used to create, capture, manipulate, communicate, exchange, present, and use information in its various forms. As the pressures of global competition and the use of Information and Communication Technologies increase, it is obvious that the institutions and the way they work with people are changing. Institutions such as retail outlets that sell goods and services to the final consumers tend to be more organised as a network and responsive. One of the key factors in achieving efficient retail operations is the adoption of information and communication technology as an enabler to improving customer satisfaction, operational efficiencies and effectiveness and by extension, profitability especially in a digitalised world.

In contemporary time, the only constant in the retailing industry is change. According to Alqahtani and Wamba (2012) the factors that have made change inevitable in the retailing industry are fluctuations in the economy, stiffer competition from both online and offline retailers, changes in consumer lifestyle and demographic and all these have combined together to make the demand and supply sides of the market very difficult to capture manually except through information technology. In Nigeria, such organised retailing outlets are springing up in major cities and they include but not limited to The Palms in the Lagos Peninsula, Ceddi Plaza in Abuja, Shoprite in Abuja and Kano, Jifatu Stores, country mall in Kano.

Competition in the industry is further heightened by the rise in the number of internet retailers which constituted very recent innovations in the Nigerian retail landscape.

In such a turbulent environment, only those retailers who can demonstrate unprecedented information technological architecture would prosper. Thus, as identified by Kasiri \& Sharda (2011) key operational areas of retailing into which technology could be deployed are merchandise tracking/pricing, supply chain monitoring,day to day selling activities and customer service delivery. However, it is doubtful Whether or not organised retailers in Nigeria are aware or taking advantage of technologies to launch themselves into the global market as done by American retail giants namely, Amazon.com and Wal-Mart.

In the marketing literature, Rogers is seen as the most influential author on technological adoption and since he published the first edition of his famous theory on adoption and diffusion of innovations in 1962, the scope of diffusion theories and associated empirical researches have broadened. Rogers (2003) synthesised research from over 508 diffusion studies and came out with the 'diffusion of innovation theory' for the adoption of innovations among individuals and organizations. Later theories of innovation adoption include Theory of Reasoned Action and Planned Behaviour (Ajzen, 1991), Unified Theory of Acceptance and Use of Technology (Venkatesh, 
Morris, Davies \& Davies, 2003) and Technology Acceptance Model (Venkatesh \& Bala, 2008).

Although many researchers have employed variables in these theories to investigate adoption of information and communication technology as it relates to operations of organised retailing from different perspectives (Zhou, 2009, Rekik, Sahin\& Dallery, 2009, Verhoef, Reinarte \& Krafft, 2010, Liu, White \& Sholtages, 2011, Alqahtan \& Wamba, 2012, Ying \& Colin, 2013 and Lai, 2016), nevertheless, the scope of these studies were narrow as they only concentrated on Radio Frequency Identification (RFID) as a technological tool for enhancing supply chain of modern retail operations; while larger operation issues such as day-to-day selling activities and in-store security have received little or none attention.

Thus, this study has attempted to expand the scope of retail operational activities to include in-store selling activities, inventory management and service delivery as natural outcome of IT adoption by modern retail outlets in Kano metropolis, Nigeria. In order to further expand the frontier of knowledge, key variables across various theories such as employee attitude, leadership influence and perceived ease of IT usage were combined in this study and interrelationships among them empirically ascertained with a view of producing a comprehensive IT adoption model for organised retailers.In essence, the aim of this study was to determine factors that enhanced IT adoption and how technology usage has helped organised retailers to achieve operational efficiency. Consequently, this study is an attempt to provide answers to the following research question:

What are the factors that enhanced IT adoption by organised retail outlets in Kano Metropolis?

How has IT adoption enhanced operational efficiency of these retail outlets?

In order to achieve objectives of this research, this paper is organised as follows: this introduction is followed by literature review, research methodology, results, discussion of findings, conclusions and recommendations in that order.

\subsection{Literature Review}

This section deals with theories that underpinned the concept of adoption of information technology as well as conceptual relationships among variables of interest.

\subsection{Information Technology and its Uses in Modern Retail Outlets}

Information technology is an umbrella term that includes all technology for the communication of information. The World Bank defines ICTs as the set of activities which facilitate by electronic means the processing, transmission and display of information. This definition overlooked the human aspects of technology and according to Zhou (2011) Information and Communication Technologies are technologies people use to share, distribute, and gather information and to communicate, through computers and computer networks. Similarly, Schurle and Stroade (2003) define information technology as the modern handling of information by electronic means, which involves its access, storage, processing, transportation or transfer and delivery. Darmawan (2001) posits that IT usage in a retailing organisation starts when a company begins to realise the need for strategic change and decides toacquire technology in its operations. This would be followed by individual level adoption when technology is utilised. Information technologies that are specifically relevant for retail operations include Point - of - Sale technology (POS), ElectronicData Interchange (EDI), Data Mining (DM) and Radio Frequency (RFID).

Point-of-Sale (POS) consists of a computer, monitor, cash drawer, receipt printer, customer display and a barcode scanner. It helps in capturing of data and customer payment information at a physical location when goods or services are bought and sold. Thus, it is a comprehensive computerised checkout system that includes a bar-code scanner, receipt printer, cash drawer, credit and debit card scanner, monitor, and inventory management software. A point-of-sale system tracks sales and identifies inventory levels in real time.

Electronic Data Interchange (EDI) consists of computer-to-computer transmission of standardised business transactions (Bamfield, 1994); and was developed as a technology for information transfer from retailer's computers to suppliers' computers.By sharing customer sales figures and demand forecasts, EDI can enhance planning and control in order to reduce inventories through the use of timely information (Bamfield, 1994). EDI is mainly used to place electronic purchase orders, generate bills of lading as well astransmit sales/inventory data.

Radio Frequency Identification (RFID) identifies items using a tag, which consists of a microchip with a coiled transmitter, the data being read by an antenna. When the tag is read by an antenna, a wide range of product information is transmitted including identity of the product, location details, price, and date of manufacturing/transportation. According to Singh (2003), RFID technology has the capacity to capture approximately 40 times more information than barcode technology.

At the heart of these technologies is data mining which is the process of extracting or mining knowledge from large amounts of data in such a way as to build predictive models for management decision-making (Han \& Kamber, 2006). In general, companies use computers to capture details of business transactions and send all relevant information to a data warehouse where it is examined and analysed to reveal the total business situation (Lee \& Siau, 2001). Data mining plays an important role for retailers, especially in customer relationship 
management (CRM), allowing retailers to gain knowledge and understanding of consumer behavior (Byrom, 2001), and to segment their customer base accordingly.

\subsection{Theories of Adoption}

Adoption refers to the stage in which a technology is selected for use by an individual or an organisation (Rogers, 2003). "Innovation" is similarly used with the nuance of a new or "innovative" technology being adopted. "Diffusion" refers to the stage in which the technology spreads for general use and application. Rogers (2003) pointed out that diffusion of innovation is an all-encompassing theory and that four factors that influenced innovation adoption are: innovation itself, nature of the society to whom an innovation is introduced, time when an innovation is introduced and communication channels used to spread information about innovation. According to Rogers (2003) individuals would adopt an innovation if they perceive that the innovation has the following attributes.

First, the innovation must have some relative advantage over an existing innovation or the status quo. Second, it is important the innovation be compatible with existing values and practices. Third, the innovation should not be too complex to use by the adopter. Fourth, the innovation must have trialability. This means the innovation can be tested for a limited time without adoption. Many potential users like to see the innovation in use by their peers and understand its benefits before they choose to adopt. Fifth, the innovation must offer observable results (Rogers, 2003). According to Rogers (2003) all exposed individuals must make a decision about whether or not to accept the innovation. The innovation-decision process is defined as the process through which an individual passes from first knowledge of an innovation to forming an attitude toward the innovation, to a decision to adopt or reject it. It should be noted however, that this theory has been criticised as being individualistic in nature and failed to admit that diffusion and adoption could fail especially when latest technology produces no progress to the adopters.

The Theory of Reasonable Action is about psychological determinants of behavioural intention and these determinants are attitude and belief. Fishbien and Ajzen (1975) defined "attitude" as individual's evaluation of an object and that "belief" is a link between an object and some attribute, while "behaviour" is a consequence. People form attitudes by considering information they have about the behaviour being considered (Parminter \& Wilson, 2003). In turn, attitudes result from an individual's beliefs about the consequences of a particular behaviour and their evaluation of those beliefs. The more individuals expect that using a technology would produce good consequences, the more they develop positive attitude towards adopting such technology. The major drawback of this theory lies in its inability to consider the role of environmental and structural issues in adoption process (Botha \& Atkins, 2005).

Closely related to theory of reasoned action is Theory of Planned Behaviour. This theory is about factors such as attitude, belief and perceived control behaviour that determine intention of a person's attitudes toward that behaviour (Ajzen, 1991). The first two factors are the same as in Theory of Reasonable Action (Fishbein and Ajzen, 1975). The third factor, known as the perceived control behaviour is the control which users perceived might limit their behavior. It should be noted that this theory focuses more on individual adopter of IT, ignoring the facts that adoption may take place in an organisational setting. Consequently, Taylor and Todd (1995) modified this theory to arrive at Decomposed Theory of Planned Behaviour which contained three main factors namely, attitude, subjective norms and perceived control by organisational leaders. These factors were assumed to influence behavioural intention and actual adoption.

Technology Acceptance Model (TAM) was introduced by Fred Davies with a view of isolating key determinants of computer acceptance that could be used to explain behaviour among broad range of end-user of computer technologies. The basic TAM model consists two specific factors: Perceived Usefulness (PU) and Perceived Ease of Use (PEU). Perceived Usefulness is the potential user's subjective likelihood that the use of a certain ICT will improve adopter's action while Perceived Ease of Use refers to the degree to which the potential user expects the target system to be effortless (Davies, 1989). However, organisational leadership which is crucial for IT usage in a company was omitted in the model.

Similarly, Venkatesh, Morris, Davies and Davies (2003) reviewed Technology Acceptance Models and the Theory of Planned Behaviour and decided to use elements of each model for a new unified model, called the Unified Theory of Acceptance and Use of Technology (UTAUT). The UTAUT has four predictors of technology users' behavioural intention and they are performance expectancy, effort expectancy, social influence and facilitating conditions. Performance expectancy relates to the degree to which the technology is expected to improve job performance. The five similar constructs for all the models reviewed namely, perceived usefulness, extrinsic motivation; job-fit, relative advantage and outcome expectations form the performance expectancy in the UTAUT model while effort expectancy captures the notions of perceived ease of use and complexity. Social influence is the degree to which an individual perceives that important others believe he or she should use the new system (Venkatesh et al., 2003). Finally, the construct, facilitating conditions deals with the degree to which a support infrastructure provided by the leader for the use of technology is believed to exist. Fundamentally, 
these four constructs are modelled to be influenced by four moderators, namely, gender, age, experience and voluntariness.

In order to build technology adoption model for retailing outlets, five constructs namely, ease of use, adopters' attitude, organization leadership, adoption and perceived usefulness were selected across adoption theories and hypothesised inter - relationship among them were empirically tested and validated in this research.

\section{Organisational Leadership and Adoption of Information Technology}

The adoption of technologies in organisations speaks to the broader issue of how the decision process unfolds in organisations. Despite the similarity to individual-level adoption, Aarons, Hurlbert and Horwitz (2011) suggest that individuals in organisations may have difficulty knowing, weighing, or selecting appropriate innovations to solve particular problems, or their decision to adopt is often complicated by organisational factors (e.g., hierarchy, culture, values), thus, organisational leadership comes in to serve as motivating factor in the use of new technology.Decision-makers in organizations are often referred to as leaders/managers and therefore leadership plays an important role in technology usage in companies, retail outlets inclusive. Leaders who possess traits such as open to risk, proactivity, flexibility, creative orientation, aggressiveness, are enthusiastic in nature and are more likely to see the need of adopting and use technology in their firms (Fillis, Johannson \& Wagner, 2004). On the other hand, those that fear technology or change, lack drive and imagination, are unwilling to learn new skills and not likely to employ technology within their organisations. Studies have shown some significant relationship between organisational leadership/manager and IT adoption. For example, Faloye (2014) found that non adoption of $E$ - business by small retail businesses in Nigeria was as a result of lack of interest of owner on E-business technology. Also, Shukla and Singh (2014) found that the involvement and support of the leader had a significant influence towards the adoption of e-business among Korean retail businesses. Thus, it is hypothesised that organisational leadership has no significant influence on IT adoption.

\section{Perceived Ease of Use and Adoption of Information Technology}

Perceived ease of use is defined as the degree to which an individual subjectively believes that using technology does not require a great deal of effort (Yaghoubi \& Bahmani, 2010). Ohk, Park and Hong (2015) add that the perceived ease of use is interpreted as the level of freedom one enjoys in using technology. If employees believe that E-business technology is difficult to use, they would develop negative attitude toward the technology. The fact that users perceived ICT to be useful does not automatically result to adoption if such a system requires extra physical effort and tedious mental exercise (Davis, 1989). Most users want a system that gives them less physical stress and little mental exercise while using it as this will determine adoption (Odumeru, 2012). Scholars on information system have empirically found perceived ease of use as a major determinant of information technology adoption (Davis, 1989; Liébana-Cabanillas et al., 2013; Pikkarainen et al., 2004). However, Chan and $\mathrm{Lu}$ (2004) found a significant indirect relationship between perceived ease of use and the intention to adopt and use new technology. Thus, it is hpothesised that ease of use has no significant influence of IT adoption.

\section{Employees' Attitude and Adoption of Information Technology}

Attitude is an individual's positive or negative behaviour towards innovation adaptation. Triandis (1979) further stated that attitude portrayed the perceptions of usefulness of technology, risk, privacy, and personal preferences. Crano and Prislin (2008) see attitude as a three factor concept, namely, cognitive, affective and conative. Cognitive factor is represented by individual's thoughts, beliefs and ideas about the object of an attitude. The cognitive aspect can be based on gained information, previous experience or simply on social stereotypes. Affective component - often called emotional - consists of feelings or emotions about the object of the attitude, such as joy, fear, hate, love, anxiety. Conative is called behavioural component and it represents individual's acting in a certainway towards or away from the object of the attitude. In the retailing sector, the attitude of IT adopters is reinforced by their evaluation of how good or bad technology has helped them to deliver superior performance. Conceptually, consumers' attitude is argued to have strong, direct, and positive effect on consumers' intentions to actually use the new technology (Hernandez \& Mazzon, 2007). It is therefore hypothesised that employees attitude has no significant effect on IT adoption.

\section{Operational Efficiency of Retail Outlets and Adoption of Information Technology}

Retailing is the set of business activities that adds value to the products and services sold to consumers for their personal or family use (Levy, 2001). Retailing is not limited to selling products and services in the stores only, but also, through many other channels including internet and direct sales. Retailers work as a link between the consumers and manufacturers of products and services. Organised retailing in Nigeria is simultaneously a promising and challenging venture as it represents a large untapped market that is likely to witness tremendous growth in the coming years. As urbanisation spreads beyond the major cities, it converts the local population 
from net savers to net spenders. Indeed, Nigerian consumers have undergone a remarkable transformation and as observed by Odumeru (2012), with the emergence of middle-class, access to credit cards, exposure to the shopping culture of the West through internet and the desire to improve their living standard, consumers in developing countries such as Nigeria are spending like never before.

One notable format of organised retail in Nigeria is the supermarket. Supermarket is a large-scale retailing institution offering a variety of merchandise (including groceries, meats and dairy products); it operates largely on a self-service basis with a minimum of customer services, and features of a price appeal as well as ample parking space (Kotler\&Keller, 2006). Although, supermarkets were originally devised as food retailing business, increasing number of supermarkets have added such non-food lines as drugs, household utensil, computer hardware, in order to widen their merchandise appeal and increase their profit potentials.

Departmental stores are large retailing institutions that carry a wide variety of product lines including apparel and other soft goods, furniture and home furnishing. Departmental stores are organised into several departments which are separate organisational units in terms of accounting, control and merchandising (Kotler \& Keller, 2006). It thus brings together under one roof a range of merchandising offerings comparable to the combined offerings of many stores specialising in single or fewer product lines. Departmental stores and supermarkets reflect the modern concept of retailing in Nigeria and are mostly found in urban centres, Kano inclusive. Although urbanisation and increased incomes have been important factors in the rise of these modern outlets, other factors also play important roles. According to Reardon and Gulati (2008) liberalisation of retail foreign direct investment and multinationalisation in the retail sector of the economy continue to play crucial role in the spread of supermarkets in the developing economies which of course, constitute the basis for this study.

In his study of benefits associated with IT usage by business organisations, Ferrer (2009) concluded that four basic benefits stand out and they are: reduction of workload through automation, shorter cycle times, and enhancement of self service and prevention of losses. Roh (2009) believes that there are cost savings benefits derivable when companies use technology and they include safety of merchadising via shop lifting, less need for labor and equipment expenses, and transparency in the supply chain. Also, USA Strategies (2005) opines that information technology usage could enhance day today selling activities such as in - store suggestive selling to customers of additional and complimentary items while they were shopping. Innovations with an unambiguous advantage in cost-effectiveness practice are more likely to be adopted and subsequently impacted on the operations of business organisations (Damanpour \& Schneider, 2009). Therefore, it is hereby hypothesised that IT adoption has no significant effects on retail operations.

\subsection{Methodology}

Cross sectional research design which involved gathering primary data on the research variables simultaneously from the respondents was adopted for this study. The population of this study was made up of 7, 200 management and staff of 76 organised modern retailing outlets in Kano metropolis. Kano metropolis which was the setting of this research consisted of six Local government Councils namely Tarauni, Fagge, Nassarawa, Gwale, Dala and Kano Municipal Local Government Areas and parts of Ungogo and Kumbotso Local Governments. Kano metropolis was chosen for this study because it is the commercial nerve centre of Northern Nigeria. Besides, Kano metropolis is the melting point for all Nigerian tribes as well as other non - Nigerians. Using table proposed by Krejcie and Morgan (1970) a sample of 400 respondents who were staff and proprietors/management of seventy-six (76) modern retailing outlets were chosen through systematic sampling technique. Guided by the list of employees of these stores every 18 employee on the sample frame was requested to participate.

The research instrument employed was a structured self - administered questionnaire designed for the purpose of collecting primary data that were relevant for the accomplishment of the goal of this study.Specifically, the questionnaire elicited responses from the respondents on the following variables, namely, bio-data of the respondents, employees' attitude, perceived ease of use; organizational leadership,

IT adoption and operational efficiency. Items on the questionnaire were adapted from previous studies conducted by Saade and Bahli (2005) as well as Shukla and Singh (2014). With the exception of bio - data of the respondents, all construct items were measured on a five-point Likert scale that ranged from $1=$ " not at all"to 5 = "to a very large extent", where the larger values represented stronger perceptions of each construct variable. The face and content validity of the draft copy of the questionnaire was confirmed by three experts in the field of information technology, marketing and sociology who presumably have sufficient knowledge on the subject matter of this study. Their comments were used to effect necessary modifications to the items on the questionnaire.

Explorative Factor Analysis (EFA) was performed on the data in order to reduce the items on the questionnaire to a manageable and meaningful set of factors. The first sets of results from this analysis are Kaiser - Meyer- Olkin (KMO) and Bartlett test of Sphericity which tested adequacy of sample size in the analysis. 
KMO values for organizational leadership ease of use, employees' attitude, IT adoption and retail operational efficiency are $0.794,0.898,0.871,0.947$ and 0.962 respective and they are significant as $\mathrm{p}<0.001$. Wu (2009) recommended that KMO values should be at least 0.7, and Bartlett's Sphericity test should be significant where $\mathrm{p}=<0.05$. Thus, the sample size is big enough for the conduct of factor analysis. Also, all the five constructs satisfied Eigen value of more than 1 and the total variance explain for these five factors ranged from $71.45 \%$ for organizational leadership, $61.71 \%$ for ease of use, $62.46 \%$ for employees' attitude, $77.82 \%$ and $70.47 \%$ for IT adoption and retail operational efficiency respectively. Similarly, all items with 0.30 loadings on the factors were included in the data analysis because a factor loading of 0.30 or above was considered to be of practical significance for any social or management science research (Hair, Babin \& Anderson, 2010).

Also, the study established the internal consistency which was guided by the computation of coefficient values of Cronbach alpha. The Cronbach Alpha values for the five subscales showed that, individual attitude $=$ 0.874 , perceived ease of use $=0.911$; organizational leadership $=0.857$, IT adoption $=0.964$ and operational efficiency $=0.968$. The reported reliability indicators are in line with recommendations of Malhotra (2010) who emphasized that the Cronbach alpha coefficient should be at least 0.70 .

Descriptive statistics were employed to explain the basic features of the respondents while Regression analysis was employed to test formulated hypotheses at $95 \%$ confidence level. Statistical Package for Social Science (SPSS v.21) was used to effect the analysis of data. The basic formula of multiple regressions as presented by Hair et al. (2010), is as below:

Regression model $\mathbf{Y}=\boldsymbol{\beta 0}+\boldsymbol{\beta 1 X 1}+\boldsymbol{\beta 2 X} \mathbf{2}+\boldsymbol{\beta 3 X} \mathbf{3}+\boldsymbol{\varepsilon}$. Where; $\mathrm{Y}=\mathrm{IT}$ adoption, $\beta 0=$ Constant Term, $\beta 1-\beta 3$ (Coefficients) $X_{1}$ - organizational leadership; $X_{2}$ - ease of use; $X_{3}$ - employees $\backslash$ attitude; $\varepsilon=$ Error term

\subsection{Results/Findings}

This section deals with collation, analysis and interpretation of the data collected for this study. It involved the descriptive analysis of the demographic data of the respondents, testing of the formulated hypotheses at $95 \%$ confidence level and discussions of findings.

\subsection{Characteristics of Respondents}

Although a total of 400 copies of the questionnaire were administered to the respondents, only 351 copies (representing 87.8\%) were found to be suitable for data analysis. A cursory look at the bio - data of the respondents showed that 284 of the respondents were male while the remaining 67 were female. This may not be unconnected with the fact that in the northern part of Nigeria which was the setting of this study females are mostly restricted to home on cultural/religious grounds. The respondents were dominated by younger persons as 144 had their age bracket within 18 - 25 years; and another 125 had their age bracket falling within $26-35$ years of age. Also, 62 respondents were within $36-45$ years age brackets while the remaining 20 were above 45 years. When they were asked to indicate their monthly income; a whopping 245 respondents earned below N30, 000 ; another 87 earned between N30, 000 and N60, 000; while the remaining 19 earned over N60, 000 per month. As for their educational qualifications, it was found that 177 respondents hold SSCE/NECO certificate; 52 hold primary school certificate while 92 others were first degree holders; the remaining 30 hold other certificates such as NCE and Diploma.They were asked to indicate their job title, data analysis showed that 142 were store attendants, 101 were cashier; 86 were managers, while the remaining were IT operators and supervisors. Turning to their year of experience, it was found that about 300 of them have spent 1 to 5 years on the job while the remaining have $6-10$ years job experience. Also, they were asked if they possess personal computer/laptop, 244 answered in affirmative while the remaining 107 depend on their stores to use computers.

\subsection{Determinants of Information Technology Adoption}

In order to provide answer to the first research question, a joint model for causal relationship was tested when IT adoption (Y) was regressed on the three independent variables, namely, organisational leadership, adopter's attitude and ease of IT use. The foundation upon which regression analysis is based is the correlation coefficients between dependent variable and each of the independent variable.

Table 4.1: Correlation Matrix and Descriptive Statistics for organisational leadership ease of use, adopter attitude and IT usage/adoption

\begin{tabular}{|l|c|c|c|c|l|}
\hline Variables & (1) & (2) & (3) & (4) & Sig. Level \\
\hline IT Adoption & 1.000 & & & & \\
\hline Organisational Leadership & 0.514 & 1.000 & & & $\mathrm{P}<0.001$ \\
\hline Ease of IT use & 0.467 & 0.763 & 1.000 & & $\mathrm{P}<0.001$ \\
\hline Adopter's Attitude & 0.417 & 0.639 & 0.698 & 1.000 & $\mathrm{P}>0.001$ \\
\hline Mean & 2.9772 & 3.7037 & 3.2934 & 3.308 & \\
\hline Standard Deviation & 1.3478 & 1.199 & 1.1720 & 1.182 & \\
\hline
\end{tabular}

Source: Survey, 2018 
The result of data analysis as presented in table 4.1 showed that the relationships between dependent variable and each of the three independent variables is positive and significant at $\mathrm{P}<0.001$.

Table 4.2: Multiple Regression Results: IT Adoption (Y) and three Explanatory Variables

\begin{tabular}{|c|c|c|c|c|c|c|c|}
\hline $\begin{array}{l}\text { No of Independent Variable } \\
\text { in the regression Equation }\end{array}$ & $\begin{array}{c}\mathrm{b} \\
\text { Coefficient }\end{array}$ & $\begin{array}{l}\text { Standard } \\
\text { Error of } b\end{array}$ & $\mathrm{t}$ & $\begin{array}{l}\text { Level of } \\
\text { sig. }\end{array}$ & $\mathrm{R}^{2}$ & $\begin{array}{l}\text { F- } \\
\text { statistic }\end{array}$ & $\mathrm{P}$ \\
\hline Organisational leadership & 0.393 & 0.081 & 4.837 & $\mathrm{P}<0.001$ & \multirow[t]{4}{*}{0.284} & \multirow[t]{4}{*}{45.610} & \multirow[t]{4}{*}{$\mathrm{P}<0.001$} \\
\hline Ease of IT use & 0.146 & 0.089 & 1.637 & $\mathrm{P}>0.005$ & & & \\
\hline Adopter Attitude & 0.119 & 0.074 & $\begin{array}{l}1 . \\
604\end{array}$ & $\mathrm{P}>0.005$ & & & \\
\hline Constant & 0.644 & 0.210 & 1.604 & & & & \\
\hline
\end{tabular}

Source: Survey, 2018

All these three independent variables featured in the regression equation, and the resulted F-statistics $=$ 45.610 and degree of freedom $=3$ which was significant at $\mathrm{P}<0.001$ (see table 4.2). The resulting F-statistic is an indication that the model is a good predictor of the dependent variable. Thus, the earlier formulated null hypothesis is hereby rejected as there is an implicit relationship between organisational leadership, ease of IT use and adopter' $\mathrm{s}$ attitude on one hand and IT adoption on the other hand. R square $\left(\mathrm{R}^{2}\right)$ is the explained variance and it showed that $28 \%$ of variation found in IT adoption has been significantly explained by the three independent variables, namely, organizational leadership, ease of use and adopter attitude. The multiple regression analysis yielded the following model (see table 4.2): IT Adoption $=0.644+(0.393)$ organisational leadership $+(0.146)$ Ease of use $+(0.119)$ Adopter's attitude.

\subsection{Effects of Information Technology Adoption on Retail Operations}

Similarly, hypothesis 2 was tested using linear regression analysis. It was found that the correlation coefficients between dependent variable (operational efficiency) and the independent variable (IT adoption) $=0.754$ which is positive and significant at $\mathrm{P}<0.001$ (see table 4.3). The result of the linear regression analysis as revealed in table 4.4 showed that Degree of Freedom $=1$, F-statistic $=460.164$ which was significant as $\mathrm{P}<0.001$, indicating that IT adoption is a good predictor of operational efficiency of modern retail outlets. Thus, the earlier formulated null hypothesis that IT adoption has no significant effects on operational efficiency of modern retail outlets is hereby rejected.

Table 4.3:Correlation Matrix and Descriptive Statistics for Operational Efficiency and IT Adoption

\begin{tabular}{|l|l|l|l|}
\hline Variables & $(1)$ & $(2)$ & Sig. Level \\
\hline Operational efficiency & 1.000 & & \\
\hline IT Adoption & 0.754 & 1.000 & $\mathrm{P}<0.001$ \\
\hline Mean & 3.2251 & 2.9772 & \\
\hline Standard Deviation & 1.3150 & 1.3478 & \\
\hline
\end{tabular}

\section{Source: Survey, 2018}

Additionally, $\mathrm{R}^{2}=0.569$ and it showed that $57 \%$ variations found in operational efficiency of modern retail outlets have been significantly explained by IT adoption. The linear regression analysis as shown in (table 4.4) yielded the following model: Operational efficiency of modern retail outlets $=1.035+(0.736)$ IT adoption.

Table 4.4:Linear Regression Results: Operational efficiency (Y) and IT Adoption

\begin{tabular}{|l|l|l|l|l|l|l|l|}
\hline $\begin{array}{l}\text { Independent Variable } \\
\text { in the Regression } \\
\text { Equation }\end{array}$ & $\begin{array}{c}|c| \\
\text { Coefficient }\end{array}$ & $\begin{array}{l}\text { Standard } \\
\text { Error of b }\end{array}$ & $\begin{array}{c}\mathbf{t} \\
\text { Statistic }\end{array}$ & $\begin{array}{l}\text { Level of } \\
\text { sig. }\end{array}$ & $\mathbf{R}^{2}$ & $\begin{array}{l}\text { F- } \\
\text { statistic }\end{array}$ & P \\
\cline { 1 - 4 } IT Adoption & 0.736 & 0.034 & 460.164 & $\mathrm{P}<0.001$ & 0.57 & 460.164 & $\mathrm{P}<0.001$ \\
\hline Constant & 1.035 & 0.112 & & & & \\
\hline
\end{tabular}

Source: Survey, 2018

\subsection{Discussions of Findings}

In this study, it was established that organizational characteristics (organizational leadership), innovation characteristics (ease of use) and adopter's characteristics (employees' attitude) collectively explained 28\% varation found in information technology adoption among employees of modern retail outlets in Kano metropolis. These findings were in conformity with the results obtained by Dubihlela and Kupangwa (2016) who examined the employee perception on the factors that influence e-business adoption and use by small and medium-sized retail enterprises in the Eastern Cape Province, South Africa. They found that leadership, employee attitude, perceived relative advantage, and perceived ease of use have a positive significant influence on IT adoption within the retail sector. Also, the findings of Alqahtani and Wamba (2012) partially supported the results of this investigation. They found that competitive pressure, technology competency and social issues to be key determinants of RFID adoption among Saudi Arabian retail stores while ease of use and organizational 
leadership/management were not significant predictors of IT adoption. However, findings by other scholars are in sharp contrast with the outcome of this investigation. For example, Plomp, Huiden and Batenburg (2011) found that the most important determinants of technology (POS) adoption among 37 Dutch small, independent retailers were the retailer's innovativeness and computer literacy.

In addition, the results of the regression analysis revealed significant predictive relationships between IT adoption and operations of retail outlets. The results showed that retail employees viewed technology adoption as vital steps towards achieving operational efficiency. This result concurred with the result obtained by Xie and Allen (2013) who conducted a comparison study of effects of IT deployment in the operations of two UK retailers. It was found that IT adoption would enhance the overall retail supply chain in terms of cost reduction, response efficiency and customer satisfaction levels. But Hassan and Parves (2013) empirically confirmed that IT adoption by two United Kingdom retail stores (Tesco and Sainsbury) has helped them to manage customer relations effectively. Specifically, these two retail stores were able to gain a clear understanding of their customers' shopping patterns with the help of IT usage.

\section{Conclusion and Recommendations}

The advent of IT offers many opportunities to the retail organisations, and is acknowledged as being useful in improving their performances and optimising business processes. Consequently, in order to predict adoption of IT by employees in an organization, scholars have investigated and replicated variables in each of adoption theories, TAM inclusive. In an attempt to contribute to extant literature on IT adoption, this study incorporated five variables across four different theories into a single study. Specifically, employees attitude which is the characteristics of adopter, leadership which is the feature of an organizational, ease of use which is the characteristics of the innovation itself, adoption and natural outcome of IT usage (operational efficiency) were incorporated into a single study and interrelationships among them were explored. It was concluded that employee's attitude, organization leadership and ease of use are significant predictors of IT adoption among retailers and that IT usage has significant effects on the operational efficiency of modern retail outlets.

It is hereby recommended that business leaders in the retail sector acquaint themselves with appropriate technology that could maximise benefits to retailers and other participants such as customer, suppliers in the retail value chain.

\section{Acknowledgement}

This paper was presented at the $12^{\text {th }}$ Annual Conference of The Academy of Management Nigeria held at Nile University of Nigeria, Abuja from October $24-25,2018$. The authors wish to acknowledge constructive comments on the initial draft of this research by scholars/participants at this conference.

\section{References}

Aarons, G. A., Hurlburt, M., \& Horwitz, S. (2011).Advancing a conceptual model of evidence-based practice implementation in public service sectors.Administration and Policy in Mental Health and Mental Health Services Research, 38(1), 4-23.

Ajzen, I. (1991). The Theory of Planned Behavior. Organization Behavior and Human Decision Processes, Academic Press.

Alqahtani, S. \& Wamba, S.F. (2012). Determinants of RFID Technology Adoption Intention in the Saudi Retail Industry: an Empirical Study, Proceedings of the 45th Hawaii International Conference on System Sciences (HICSS-45), Maui, Hawaii, January 4-7, 2012.

Bamfield, J.A.N. (1994) 'Implementing EDI: problems in managing retail/supplier relationships by technology', Logistics Information Management, 7(1), 7-10.

Botha, N. \& Atkins,K. (2005), An assessment of five different theoretical frameworks to study the uptake of innovations, Paper presented at the 2005 NZARES Conference Tahuna Conference Centre - Nelson, New Zealand. August 26-27, 2005.

Byrom, J. (2001). 'The role of loyalty card data within local marketing initiatives', International Journal of Retail \& Distribution Management, 29(7), .333-341.

Chan, S. \& Lu, M. (2004). Understanding internet banking adoption and use behaviour: A Hong Kong perspective. Journal of Global Information Management, 12(3), 21-43.

Crano, W. D. \& Prislin, R. (2008).Attitudes and Attitude Change. New York: Psychology Press.

Davis, F. D. (1989). Perceived Usefulness, Perceived Ease of Use, and User Acceptance of Information Technology. MIS Quarterly, 13(3), 319-340.

Dubihlela, J. \&Kupangwa, W. (2016).Employee Perspectives of Factors Influencing E-Business Technology Adoption and use by Small and Medium Retail Enterprises, International Journal of Business and Management Studies, 8(1), 1 - 19

Damanpour, F. \& Schneider, M. (2009). Characteristics of Innovation and Innovation Adoption in Public 
Organizations: Assessing the Role of Managers. Journal of Public Administration Research and Theory, 19(3), 495-522.

Darmawan, I. G. N. (2001), Adoption and Implementation of Information Technology in Bali's local Government: A Comparison Between Single Level Path Analysis using PLSATH 3.01 and AMOS 4 and Multi Level Path Analyses using MPLUS 2.01, International Education Journal, 2(4),100-112.

Faloye, D.O. (2014). The Adoption of E-commerce in Small Businesses: An Empirical Evidence from Retail Sector in Nigeria. Journal of Business and Retail Management Research, 8(2), 54-64.

Fillis, I., Johannson, U. \& Wagner, B. (2004).Factors Impacting on E-business Adoption and Development in the Smaller Firm, International Journal of Entrepreneurial Behavior \& Research, 10(3), 178-191.

Ferrer, G. (2009). When is RFID right for your service? International Journal of Production Economics, 124(2), 414-425.

Fishbein, M. and Azjen, I. (1975).Belief, Attitude, Intention and Behaviour: An Introduction toTheory and Research. Reading, MA: Addision-Wesley.

Hair, J.F., Black, B.J., Babin, B.\& Anderson, R.E. (2010).Multivariate Data Analysis - Vectors, 7th Ed, Pearson Prentice Hall. London.

Hassan, A. \& Parves, M. (2013).A Comparative Case Study Investigating the Adoption of Customer Relationship Management (CRM) The Case of Tesco and Sainsbury's, International Journal of Managing Value and Supply Chains, 4(1), 1 - 10

Hernandez JMC, Mazzon JA (2007). Adoption of internet banking: proposition and implementation of an integrated methodology approach, International J. Bank Mark. 25 (2): 72-88.

Jeon, B.M., Han, K.S. \& Lee, M.J. (2006). Determining factors for the adoption of e-business: The case of SMEs in Korea, Applied Economics, 38(1):1905-1916.

Kasiri, N., Sharda, R. \& Hardgrave B. (2011). A Balanced Scorecard for Item-Level RFID in theRetail Sector, European Journal of Information Systems, 1(2), 10 - 20.

Kotler, P. \& Keller, K. L. (2006).Marketing Management, $12^{\text {th }}$ Edition, Prentice-Hall of India Private Limited, New Delhi

Krejcie, R. \& Morgan, D. (1970) Determining sample size for research activities, Educational and Psychological Measurement, 30(3), 607-610

Levy, M., \& Wietz, B. (2001).Retailing Management.McGraw-Hill Higher Education, N. Y.

Lee, S.J. \& Siau, K. (2001). A Review of Data Mining Techniques, Industrial Management \& Data System, 101(1),41-46.

Liébana-Cabanillas, F., Muñoz-Leiva, F., \& Rejón-Guardia, F. (2013).The determinants of satisfaction with ebanking.Industrial Management \& Data Systems, 113(5), 750- 767.

Maholtra, N. K. (2010).Marketing Research: An Applied Orientation. $6^{\text {th }}$ edition. Pearson Education, New York

Odumeru, J. A. (2012). The Acceptance of E-banking by Customers in Nigeria, World Review of Business Research, 2(2), 62-74.

Pikkarainen, T., Pikkarainen, K., Karjaluoto, H. \& Pahnila, S. (2004). Consumer Acceptance of Online Banking: An Extension of the Technology Acceptance Model", Internet Research, 14(3), 224-35.

Plomp, G. A., Huiden, R. P. \& Batenburg, R. S. (2011).Determinants of Point-of-Sale System Adoption: A Survey among Small Retailers in the Netherlands, Proceedings of the Seventeenth Americas Conference on Information Systems, Detroit, Michigan August $4^{\text {th }}-7^{\text {th }}, 2011$

Readon, T. \& Gulati, A. (2008). The Supermarket Revolution in Developing Countries: Policies for Competitiveness with Inclusiveness, Website: http://www.ifpri.org/pubs/bp/bp002.asp pp 1 - 6

Roh, J,. 2009. Classification of RFID adoption: An expected benefits approach. Information \& Management, Volume-46, Issue 6, Pages 357-363.

Rogers, E. M. (2003). Diffusion of innovations (5th ed.). New York: Free Press.

Rekik, Y., E. Sahin, E. \& Dallery, Y. (2009).Inventory Inaccuracy in Retail Stores due to theft: An Analysis of the Benefits of RFID, .International Journal of Production Economics, 118(1),189-198.

Saade, R., \& Bahli, B. (2005).The Impact of Cognitive Absorption on Perceived Usefulness and Perceived Ease of Use in On-line Learning: An Extension of the Technology Acceptance Model, Information and Management, 42(1), 317-327.

Shukla, T. \& Singh, A. (2014).Employee Perception towards Technology in Banking Sector.Research Journal of Social Science \& Management, 4(2), 85-94.

Schurle, B. \& Stroade, J.L. (2003). Factors Influencing Information Technology Adoption: A CrossSectionalAnalysis, Website: http://ageconseargh.umn.edu/bitstream/35015/1/sp03st04.

Singh, N. (2003).Emerging Technologies to Support Supply Chain Management, Communication of the ACM, 46(9),243-247.

Taylor, S.\& Todd, P. A. (1995).Understanding Information Technology Usage: A Test of Competing Models, Information Systems Research, 6(2), 144-176. 
Triandis HC (1979). Values, attitudes and interpersonal behaviour.Unpublished paper, University of Nebraska Press, Lincoln, NE.

USA Strategies (2005).RFID Adoption in the Retail Industry.USA Strategies, Inc, Willowbrook, USA

Venkatesh, V., Morris, M. G., Davis, F. D., \& Davis, G. B. (2003). User Acceptance of Information Technology: Toward a Unified View. MIS Quarterly, 2(7), 425-478.

Venkatesh, V. \& Bala, H. (2008).Technology Acceptance Model 3 and a Research Agenda on Interventions, Decision Science, 39(2), 273-312.

Verhoef, P. C., Werner R. \& Manfred Krafft (2010). Customer Engagement as a New Perspective in Customer Management, Journal of Service Research, 13 (3), 247-252.

$\mathrm{Wu}$, D. (2009). Alternative Tests of Independence Between Stochastic Regressors and Disturbances, Econometrica, 41(4), 733-750.

Xie, Y. \& Allens, C. (2013).Information Technologies in Retail Supply Chains: A comparison of Tesco and Asda, International Journalof. Business Performance and Supply Chain Modeling, 5(1), 46 -59.

Yaghoubi, N. M. \& Bahmani, E. (2010).Factors Affecting the Adoption of Online Banking.International Journal of Business and Banking, 5(9), 150-165.

Zhou, T. (2011). An Empirical Examination of Initial Trust in Mobile Banking, Internet Research, 21(5), 527540. 